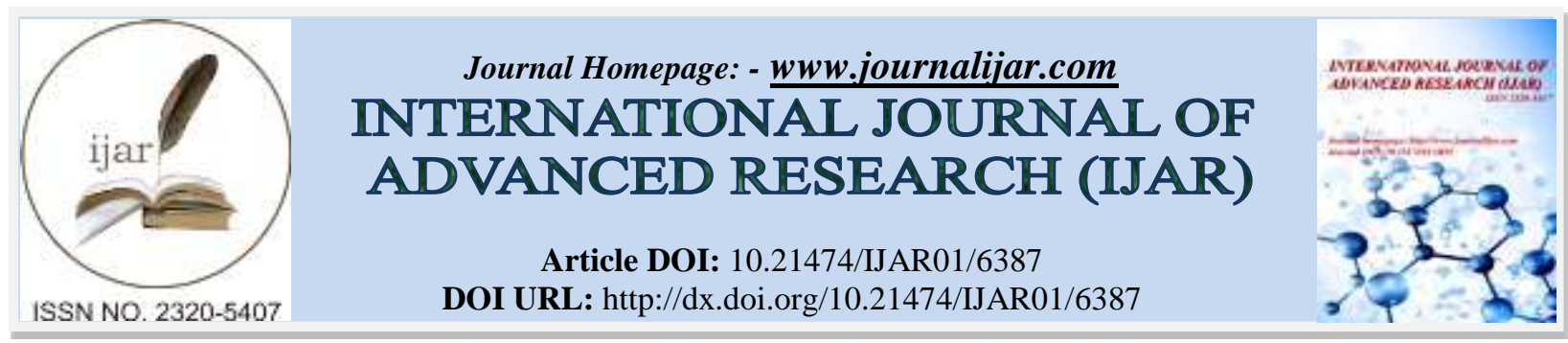

RESEARCH ARTICLE

\title{
THE COMBINATION OF GUIDED INQUIRY WITHSOROGAN TRADITIONAL MODEL AND THEIR COMBINATION EFFECTIVITY IN STUDENTS METACOGNITIVE PERFORMANCE
}

\author{
Enki Dani Nugroho', ${ }^{1}$ Suratno $^{2}$ and Imam Mudakir ${ }^{1}$. \\ University of Jember, Jember, Indonesia.
}

\section{Manuscript Info}

Manuscript History

Received: 23 November 2017

Final Accepted: 25 December 2017

Published: January 2018

Key words:-

Guided inquiry, traditional model, sorogan, metacognitive, natural science, madrasah tsanawiyah.

\begin{abstract}
To identify the effect of the combination of guided inquiry with sorogan traditional model in students metacognitive performance, in natural science subjects, mainly in madrasah tsanawiyah school. a total of 20 students in grade $7 \mathrm{~B}$, in Madrasah Tsanawiyah Negeri 11 Jember, Indonesia, participated in this study. The research design applied for this study was a One Group with Pre-Test and Post-Test research design, in the two sessions of the class, with a different subject matter for each class session. The Metacognitive Awareness Inventory (MAI) was used to assess the students metacognitive performance, and One Sample Kolmogorov-Smirnov test with Paired Sample T-test in SPSS 17.0 were used to analyze data in this study. The result showed a significant effect of the combination model in students metacognitive performance. The analysis revealed that there was a statistically significant difference between pre-test values and post-test values, after the combination model implemented. Hence, the combination of guided inquiry with sorogan traditional model potentially effective to enhance students metacognitive performance, particularly in natural science subjects, in Madrasah tsanawiyah school.
\end{abstract}

Copy Right, IJAR, 2018,. All rights reserved.

\section{Introduction:-}

There were various metacognitive definition (e.g. Flavell, 1979 and Livingston, 1997). Flavell (1979) declared that metacognitive refers to one's knowledge concerning one's own cognitive processes or anything related to them. Livingston (1997) supported Flavell (1979) that metacognitive refers to higher order thinking which involves active control over the cognitive processes engaged in learning. Metacognitive was divided into two components, knowledge about cognition and regulation of cognition (Brown, 1978; and Flavell, 1979). The knowledge about cognition components refers to how much learners understand about their own memories and the way they learn (Brown, 1978). Livingston (1997) supported Brown (1978) that knowledge about cognition components refers to general knowledge about how human beings learn and process information, as well as individual knowledge of one's own learning process. The regulation of cognition refers to how well learners can regulate their own memory and learning (Brown, 1978). Further Livingston (1997) declared that the regulation of cognition was a sequential process that one uses to control cognitive activities. 
The knowledge about cognition components was divided into three aspects, declarative knowledge or knowledge about one's general processing abilities, procedural knowledge or knowledge such as how to succesfully solve problems, and conditional knowledge or knowledge such as when to employ specific strategies (Paris et.al., 1984; Palincsar \& Brown, 1987; Schraw, 1994 and 1997; and Schraw \& Nietfeld, 1998). The regulation of cognition was divided into several aspects, planing, selecting, monitoring, evaluating, and debugging (Paris et.al., 1984; and Schraw \& Dennison, 1994). Different depictions of metacognitive aspects, development of tools for measuring those aspects, and strategies for teaching those aspects to students were all active areas of inquiry (Schraw et.al., 2006; and Zohar, 2009). Metacognitive was an important component in the domain of inquiry learning (Dedic, 2014). Inquiry learning also called inductive learning (Beishuizen, et.al., 2004; and Veenman \& Spaans, 2005), defined as an educational activity in which learners investigate real or virtual phenomena and draw conclusions based on what they have learned regarding the causal status of the features in a multivariable system (Kuhn, 2000).

Inquiry learning was divided into three levels based on complexity levels, consists of discovery learning, guided inquiry learning, and open inquiry learning (Trowbridge \& Bybee, 1990). Inquiry was a rational intellectual process and enjoyfull to describe science (Ting, 2001). Hebrank (2000) also declares that inquiry was an art of asking questions about natural science phenomenon. Furthermore, inquiry also called as a learning model that prepares situations for students to conduct experimental activities (Piaget, 1964). Trowbridge \& Bybee (1990) introduced inquiry as a process of defining and investigating problem, formulating hypotheses, planing experiment, collecting data, and formulating conclusion. Vlassi \& Karaliota (2013) found that 138 studies were analyzed and indicate a positive trend favoring inquiry-based learning practice, and instruction that emphasize student active thinking and drawing conclusions from data. However, studies of inquiry-based learning practice needs to be further developed, particularly inquiry-based learning through the combination of guided inquiry with a traditional model sorogan, particularly on students metacognitive performance, in natural science subjects.

\section{Research Design:-}

One Group with Pre-test and Post-test research design was applied for this study, in the two sessions of the class, with different subject matter for each class session, the plant organs and the chemical mixture. Both pre-test and post-test, students must complete the Metacognitive Awareness Inventory (MAI) to assess their metacognitive performance. The pre-test was given to identify an initial students metacognitive performance, before the combination model implemented, the post-test was given to identify a final students metacognitive performance, after the combination model implemented.

\section{Participants:-}

a total of 20 students in grade 7 B, in the first semester, 2017/2018 academic year, from Madrasah Tsanawiyah Negeri 11 Jember, Indonesia, participated in this study. Before determining the sample class, the Levene test in SPSS 17.0 was applied to the last daily test score from all grades 7 to identify the homogenity of the sample in this study. The Levene test result showed that all samples were homogeneous, and random selection was applied to determine the one class to be used in this study as a sample class.

\section{Instrument:-}

The instrument used in this study was the Metacognitive Awareness Inventory (MAI) from Schraw \& Dennison (1994), which translated in Indonesian, to assess students metacognitive performance, contains of 52 items metacognitive performance statements, a 17 items for knowledge about cognition aspects and 35 items for regulation of cognition aspects. The knowledge about cognition statements consists of statement numbered $3 ; 5 ; 10$; $12 ; 14 ; 15 ; 16 ; 17 ; 18 ; 20 ; 26 ; 27 ; 29 ; 32 ; 33 ; 35$; and 46 . Then, the regulation of cognition statements consists of statement numbered $1 ; 2 ; 4 ; 6 ; 7 ; 8 ; 9 ; 11 ; 13 ; 19 ; 21 ; 22 ; 23 ; 24 ; 25 ; 28 ; 30 ; 31 ; 34 ; 36 ; 37 ; 38 ; 39 ; 40 ; 41 ; 42 ; 43$; $44 ; 45 ; 47 ; 48 ; 49 ; 50 ; 51$; and 52 . Students must fill out that instrument by giving a check $(\sqrt{ })$ in a relevant statements with their own metacognitive abilities. Score 1 for "True" answer and score 0 for "False" answer.

\section{Data Collecting and Analysis:-}

This study took a place from the November $18^{\text {th }}$ to the November $25^{\text {th }}$ in 2017 . All of data analyzed with descriptive and inferential statistics. the descriptive statistics were used to summarize the demographic information from the data, and the inferential statistics were used to test the hypothesis of this study. The descriptive statistics consists of frequency, mean, and standart deviation from the data, and the inferential statistics consists of One Sample Kolmogorov-Smirnov test and Paired Sample T-test in SPSS 17.0 to analyze the data from Metacognitive 
Awareness Inventory (MAI). Both knowledge about cognition aspects and regulation about cognition aspects analyzed separately with these test.

\section{Result and Discussion:-}

Table 1:- Kolmogorov-Smirnov Test (Plant Organs)

\begin{tabular}{|c|c|c|c|c|}
\hline Test & Component & N & Mean & Sig. \\
\hline Pre-Test & Knowledge about Cognition & 20 & 11.10 & 0.258 \\
\hline Post-Test & & 20 & 12.00 & 0.400 \\
\hline Pre-Test & Regulation of Cognition & 20 & 22.20 & 0.652 \\
\hline Post-Test & & 20 & 23.45 & 0.405 \\
\hline
\end{tabular}

Table 1. shows that the Sig. value of Kolmogorov-Smirnov test in knowledge about cognition, both pre-test and post-test aspects were 0.258 and $0.400, P>0.05$. Therefore, it can be concluded that data in both aspects was normally distributed. Table 1. also shows that the Sig. value of Kolmogorov-Smirnov test in regulation of cognition, both pre-test and post-test aspects were 0.652 and $0.405, P>0.05$. Hence, it can be concluded that data in both aspects was normally distributed.

Table 2:- Paired Sample T-Test (Plant Organs)

\begin{tabular}{|c|c|c|}
\hline Pair & Component & Sig. \\
\hline Pre-Test - Post-Test & Knowledge about Cognition & 0.000 \\
\hline Pre-Test - Post-Test & Regulation of Cognition & 0.000 \\
\hline
\end{tabular}

Table 2. shows that the Sig. value from both knowledge about cognition and regulation of cognition components were $0.000, P<0.05$. Therefore, it can be concluded that there was a statistically significant difference, between pretest and post-test values from both components.

Table 3:- Kolmogorov-Smirnov Test (Chemical Mixture)

\begin{tabular}{|c|c|c|c|c|}
\hline Test & Component & N & Mean & Sig. \\
\hline Pre-Test & Knowledge about Cognition & 20 & 11.40 & 0.307 \\
\hline Post-Test & & 20 & 12.65 & 0.298 \\
\hline Pre-Test & Regulation of Cognition & 20 & 22.40 & 0.720 \\
\hline Post-Test & & 20 & 23.45 & 0.803 \\
\hline
\end{tabular}

Table 3. shows that the Sig. value of Kolmogorov-Smirnov test in knowledge about cognition, both pre-test and post-test aspects were 0.307 and $0.298, P>0.05$. Therefore, it can be concluded that data in both aspects was normally distributed. Table 3. also shows that the Sig. value of Kolmogorov-Smirnov test in regulation of cognition, both pre-test and post-test aspects were 0.720 and $0.803, P>0.05$. Hence, it can be concluded that data in both aspects was normally distributed.

Table 4:- Paired Sample T-Test (Chemical Mixture)

\begin{tabular}{|c|c|c|}
\hline Pair & Component & Sig. \\
\hline Pre-Test - Post-Test & Knowledge about Cognition & 0.000 \\
\hline Pre-Test - Post-Test & Regulation of Cognition & 0.000 \\
\hline
\end{tabular}

Table 4. shows that the Sig. value from both knowledge about cognition and regulation of cognition components were $0.000, P<0.05$. Therefore, it can be concluded that there was a statistically significant difference, between pretest and post-test values from both components.

The combination of guided inquiry with the sorogan traditional model has a syntax to be done as follows:

1. Defining Problem:- Students were given a problem, that prepared by the teacher.

2. Formulating Hypothesis:- Students were assigned by the teacher to formulate individual hypothesis.

3. Collecting Data:- Students were assigned by the teacher to collect data, individually, to prove their hypothesis through observation and practice activities.

4. Analyzing Data:- Students were assigned by the teacher to organize and analyze data, individually, from data collecting activities.

5. Formulating Individual Conclusion:- Students were assigned by the teacher to formulate individual conclusion. 
6. Communicating Individual Conclusion:- Students were assigned by the teacher to orally communicate individual conclusion, alternately, in front of their team-mates. In this stage, students also assigned by the teacher to compile a brief summary, individually, containing individual conclusions from each team-mates.

7. Formulating Group Conclusion:- Students were assigned by the teacher to formulate group conclusion, based on data or information from their brief summary, through group discussion.

8. Communicating Group Conclusion:- The delegates from each group were assigned by the teacher to orally communicate their group conclusion, alternately, in front of class.

9. Drawing Class Conclusion:- Students were given reflection and guided by the teacher to draw a class conclusion.

10. Correlating Information:- Students were given an additional information from the teacher, by correlating the information they have acquired with a relevant knowledge from religious aspects.

The syntax consists of a combination of guided inquiry stages and sorogan aspects and were expected to facilitate and guide students to obtain and process information through a scientific process, not only individually but also in groups. The model also expected to be relevant with characteristics of natural science subjects on junior high school level or madrasah tsanawiyah school and also relevant with learning culture in madrasah. Guided inquiry was the information-processing family of models (Joyce et.al. 2010) and was a cognitive model that relevant with science learning in school (Joyce et.al. 2000). Junior high school-age students were in operational formal phase, means that they've been able to thinking logically with their own preposition and hypothesis but still need a teacher's guidance (Piaget, 1964). There were various studies shows the impact of guided inquiry in student learning (e.g. Harada, 2002; Todd, 2006; Kim \& Todd, 2008; and Todd, 2010). The sorogan traditional model basically was a form of individual tutorial, and useful as a foundation for students to proceed, review, and discuss the information, which associated with learning activities in madrasah (Tan, 2012).

The analysis revealed that both knowledge about cognition and regulation of cognition components were statistically significant difference, between their pre-test and post-test values, after the combination of model implemented. Knowledge about cognition and regulation of cognition components of metacognition, were strongly related to each other (Sperling et.al. 2004). The results of this study also relevant with Fitzgerald (2011) concluded that guided inquiry-based learning has enhanced learning and metacognition. Flavell (1979) and Livingston (1996) found that metacognitive and cognitive knowledge might not be different, and the distinction between them lies only in how the information was used. The model characteristics in this study relevant with the concept of promoting students metacognition from Nickerson et.al. (1985) who declared that metacognition has been linked to improving thinking skills and promoting conceptual change in younger students. White \& Gunstone (1989) and Georghiades (2000) were supported that concept. Adey \& Shayer (1993) and Kuhn \& Pearsall (1998) were indicated that improve students metacognitive was associated with promoting young student's overall academic success. Tanner (2012) concluded that introduce metacognition to science educators and students were very important aspect, to support science teaching and learning activities.

\section{Conclusion:-}

This study concluded that both knowledge about cognition and regulation of cognition components, were statistically significant different, between pre-test and post-test values, after the combination of guided inquiry and sorogan traditional model implemented. That results indicated that the combination model potentially effective to enhance students metacognitive performance, particularly in natural science subjects, on junior high school level (e.g. madrasah tsanawiyah school).

\section{References:-}

1. Adey, P., \& Shayer, M. 1993. an Exploration of Long-Term Far-Transfer Effects Following an Extended Intervention Program in the High School Science Curriculum. Cogn Instr. 11. 1-29.

2. Beishuizen, J., Wilhelm, P., \& Schimmel, M. 2004. Computer-Supported Inquiry Learning: Effects of training and practice. Computers \& Education. 42. 389-402.

3. Brown, A.L. 1978 Knowing When, Where, and How to Remember: a Problem of Metacognition. Advances in Instructional Psychology. 1. 77-165.

4. Brown, A.L. 1987. Metacognition, Executive Control, Self-Regulation, and Other More Mysterious Mechanism. In F. Weinert \& R. Kluwe (Eds.), Handbook of ChildPsychology: Vol. 3. Cognitive Development. 263-340. New York: Wiley 
5. Dedic, Z.R. 2014. Metacognitive Knowledge in Relation to Inquiry Skills and Knowledge Acquisition Within a Computer-Supported Inquiry Learning Environment. Psychological Topics. 23(1). 115-141.

6. Fitzgerald, L. (2011). Does Guided Inquiry Enhance Learning and Metacognition?. School of Information Studies. Faculty of Education. Charles Sturt University.

7. Flavell, J.H. 1979. Metacognition and Cognitive Monitoring: a New Area of Cognitive-Developmental Inquiry. American Psychologist. 34. 906-911.

8. Georghiades, G. 2000. Beyond Conceptual Change Learning in Science Education: Focus on Transfer, Durability, and Metacognition. Educ Res. 42. 119-139.

9. Harada, V.H. 2002. Personalizing the Information Search Process: a Case Study of Journal Writing with ElementaryAge Students in School Library Media Research. 5.

10. Hebrank, M. 2000. Why Inquiry-Based Teaching and Learning in the Middle School Science Classroom?. Center for Inquiry-Based Learning Dept. of Biology. Duke University.

11. Joyce, B. \& Weil, M. with Calhoun, E. 2000. Models of Teaching $6^{\text {th }}$ Edition. Boston: Allyn and Bacon.

12. Joyce, B. \& Weil, M. with Calhoun, E. 2010. Models of Teaching $6^{\text {th }}$ Edition. Boston: Allyn and Bacon.

13. Kim, S.U. \& Todd, R.J. 2008. The Information Search Process of English Language Learner (ELL) Students in Guided Inquiry Project: an In-Depth Case Study of Two Korean High School Students in the United States in Information Research. 13(4).

14. Kuhn, D. 2000. Metacognitive Development. Current Directions in Psychological Science. 9(5). 178-181.

15. Livingston, J.A. 1996. Effects of Metacognitive Instruction on Strategy Use of College Students. Unpublished Manuscript. New York: State University of New York.

16. Livingston, J.A. 1997. Metacognition: an Overview. New York: State University of New York.

17. Nickerson, R.S., Perkin, D.N., \& Smith, E.E. 1985. The Teaching of Thinking. Hillsdale: NJ Lawrence Erlbaum.

18. Palincsar, A.M., \& Brown, D.A. 1987. Enhancing Instructional Time Through Attention to Metacognition. Journal of Learning Disabilities. 20. 66-75.

19. Paris, S., Cross, D.R., \& Lipson, M.Y. 1984. Informed Strategies for Learning: a Program to Improve Children's Reading Awareness and Comprehension. Journal of Educational Psychology. 76. 1239-1252.

20. Piaget, J. 1964. "Development and Learning”. Journal of Research in Science Teaching, 2:176-186.

21. Schraw, G. 1994. The Effect of Metacognitive Knowledge on Local and Global Monitoring. Contemporary Educational Psychology. 19. 143-154.

22. Schraw, G. 1997. The Effect of Generalized Metacognitive Knowledge on Test Performance and Confidence Judgments. The Journal of Studyal Education. 65. 135-146.

23. Schraw, G., \& Dennison, R.S. 1994. Assessing Metacognitive Awareness. Contemporary Educational Psychology. 19. 460-475.

24. Schraw, G., \& Nietfeld, J. 1998. a Further Test of the General Monitoring Skill Hypothesis. Journal of Educational Psychology. 90. 236-248.

25. Schraw, G., Crippen, K., \& Hartley, K. 2006. Promoting Self-Regulation in Science Education: Metacognition as Part of a Broader Perspective on Learning. Res. Sci. Edu. 36. 111-139.

26. Sperling, R.A., Bruce, C.H., \& Richard, S. 2004. Metacognition and Self Regulated Learning Constructs. Educational Research and Evaluation. Vol.10. 2. 117-139.

27. Tan, C. 2012. Islamic Education and Indoctrination: The Case in Indonesia. London: Routledge Publishing Company.

28. Tanner, K.D. 2012. Promoting Student Metacognition. CBE Life Sci Edu 11(2). 113-120. San Francisco, CA: Department of Biology. San Francisco State University.

29. Ting, C.Y. 2001. Enhancing Learner's Conceptual Change in Physics: Toward the Development of Multimedia Cognitive Tools. Malaysia: Faculty of Information Technology Multimedia University Cyberjaya.

30. Todd, R.J. (2011a). Charting Student Learning Through Inquiry in School Library Monthly. 28(3). 5-8.

31. Todd, R.J. (2011b). From Literacy to Inquiry: a Holistic Approach to Literacy Development in Selected Australia Schools. IFLA 2012. Puerto Rico.

32. Trowbridge, L.W., \& Bybee, R.W. 1990 Becoming a Secondary School Science Teacher. Melbourne: Merill Publishing Company.

33. Veenman, M.V.J., \& Spaans, M.A. 2005. Relation Between intellectual and Metacognitive Skills: Age and Task Differences. Learning and Individual Differences, 15, 159-176.

34. Vlassi, M. \& Karaliota, A. 2013. The Comparison Between Guided Inquiry and Traditional Teaching Method: a Case Study for the Teaching of the Structure of Matter to $8^{\text {th }}$ grade Greek Students. Procedia-Social and Behaviorial Sciences. 93. 494-497.

35. White, R.T., \& Gunstone, R.F. 1989. Metalearning and Conceptual Change. Int J Sci Educ. 11. 577-586.

36. Zohar. 2009. Paving a Clear Path in a Thick Forest: a Conceptual Analysis of a Metacognitive Component. Metacognition Learning. 4. 177-195. 